\title{
THE IMPACT OF THE DIAMETER TO HEIGHT RATIO ON THE COMPRESSIBILITY PARAMETERS OF SATURATED FINE-GRAINED SOILS
}

\author{
T. Nguedia Rosine ${ }^{1}$, T. Toma Sabbagh ${ }^{2}$ \\ ${ }^{1}$ Ph.D. student, Civil Engineering Research Group, The University of Salford, School of Computing, Science and \\ Engineering, Newton Building, Salford, Greater Manchester, M5 4WT, UK \\ ${ }^{2}$ Lecturer, Civil Engineering, The University of Salford, School of Computing, Science and Engineering, Newton \\ Building, Salford, Greater Manchester, M5 4WT, UK
}

\begin{abstract}
Compressibility parameters of fine-grained soils are mainly influenced by soil mineralogy, moisture content and soil diameter to height ratio $(D / H)$. The British and American standards suggested that to obtain accurate engineering properties; it is necessary to use $\mathrm{D} / \mathrm{H}$ ratio of 4 and 2.5 respectively to eliminate friction between the soil and the structure. In the current study, various D/H ratios were adopted ranging from 0.5 to 11 . The D/H ratios effect on some compressibility parameters such as coefficient of consolidation $\left(c_{v}\right)$, compression index $\left(c_{c}\right)$ and coefficient of volume compressibility $\left(m_{v}\right)$ were analysed. Additionally, the impact of the $\mathrm{D} / \mathrm{H}$ ratio on the acquire $c_{v}$ values were also presented where three methods were used namely: Casagrande, Taylor and Inflection method. The scaling effects based on $c_{v}$ ratio $\left[c_{v}(\sqrt{t}) / c_{v}(\log t)\right]$ from Oedometer tests using different D/H ratios are also presented. The results showed that Taylor's method is the most appropriate way to achieve an accurate $c_{v}$ and an increase in pressure leads to a reduction in $c_{c}$ and a gradual decrease in $m_{v}$. The validation of the experimental results on a finite element software package PLAXIS was completed.
\end{abstract}

Keywords: Compressibility, D/H ratio, Fine-grained soil, Friction

\section{INTRODUCTION}

The diameter to height $(\mathrm{D} / \mathrm{H})$ ratio criteria is used to reduce friction between the soil and structure. The American Standard suggested a minimum value of 2.5 with a value greater than four most suitable [5]. While the British Standard proposed a value of 4 with a cell diameter of $75 \mathrm{~mm}$ and height $20 \mathrm{~mm}$ are mostly applicable [10]. No available data were found to validate the $\mathrm{D} / \mathrm{H}$ ratio proposed by the American Standard. Morris and Lockington [21] conducted a self-weight consolidation test on fine-grained marine, riverine and lacustrine soils with a diameter to height $(\mathrm{D} / \mathrm{H})$ ratio ranging from 1.9 to 4.1 . The findings showed that the final void ratio were relatively comparable and was due to the sample particle sizes. Morris and Lockington neglected the effect of $\mathrm{D} / \mathrm{H}$ ratio from the selfweight consolidation test. Berry and Reid [8] stated that the greater the soil thickness, the more likely friction will occur, and smaller soil sample have no friction.

During conventional consolidation test, the lateral pressure acting on the side walls of the sample container produce frictional resistance to the compression of the sample. Taylor [26] investigated the effect of side friction in consolidation tests and showed that the frictional force varies from $12-22 \%$ of the applied pressure for remoulded clay and $10-15 \%$ for undisturbed clay. Therefore, the thinner the sample the less side friction due to the small lateral surface area in contact with the wall of the Oedometer apparatus. Leonards and Girault [19] used steel Oedometer cell and show that friction can significantly alter the result. Thus, by applying greased Teflon, it eliminates friction provided the $\mathrm{D} / \mathrm{H}$ ratios exceed six. Sivrikaya and Togrol [25] investigated the effect of clay thickness on secondary compression. Sivrikaya and Togrol [25] designed a new Oedometer cell capable to measure the frictional effect between the specimen and the cell. The outcomes revealed that side friction does not remain constant with time but slightly increases at a decreased rate. Kolay and Bhattacharya [17] conducted consolidation tests on kaolin soil with Teflon large diameter $(120 \mathrm{~mm})$ with a $\mathrm{D} / \mathrm{H}$ ratio six. The comparison of the results of previous tests $(\mathrm{D} / \mathrm{H}$ ratio 3) with Kolay's investigation showed that $\mathrm{c}_{\mathrm{v}}$ is affected by the apparatus side friction and a correction factor for different consolidation characteristics was applied. The correction factor derived by Kolay and Bhattacharya [17] was to reduce side friction.

The effect of $\mathrm{D} / \mathrm{H}$ ratio scale was not previously investigated on $\mathrm{c}_{\mathrm{c}}$ and $\mathrm{m}_{\mathrm{v}}$. The importance of $\mathrm{c}_{\mathrm{c}}$ is in the direct calculation of settlement of structures from the relationship of pressure and void ratio. It is used as its value does not change with a change in confining pressure for normally consolidated clays $[1,24]$. On the other hand, $m_{v}$ is also the most suitable compressibility parameters for direct settlement calculation. Its variability with confining pressure makes it less useful when correlating with some engineering properties [24]. Hence, $c_{c}$ and $m_{v}$ have been studied to 
obtain a relationship with some design parameters. These parameters include internal friction angle, recompression index $\left(\mathrm{c}_{\mathrm{r}}\right)$, moisture content, liquid limit (LL) and specific gravity $\left(\mathrm{G}_{\mathrm{s}}\right)$.

On the other hand, the effect of $\mathrm{D} / \mathrm{H}$ ratio on some engineering properties such as shear strength $(\tau)$, modulus of elasticity (E) and the stress-strain relationship was previously investigated. These design parameters were studied using Triaxial and Oedometer tests. Dirgeliene and Stragys [14] proposed a reduction in the standard D/H ratio in Triaxial test from 2 to 1 to eliminate friction. While Grisso et al. [15] showed that the D/H ratio of a Triaxial soil sample has little effect on the compacted soil as compared to smaller D/H ratio. On the other hand, during Triaxial testing, it was observed that at constant cell pressure, the modulus of elasticity decreases with an increase in the D/H ratio [18]. In the current study, the effect of $\mathrm{D} / \mathrm{H}$ ratios on compressibility parameters is presented and it effect of $\mathrm{c}_{\mathrm{v}}$ ratio $\left[c_{v}(\sqrt{t}) / c_{v}(\log t)\right]$. More emphasis are employed in the different method used to obtain $\mathrm{c}_{\mathrm{v}}$ and the how much impact the $\mathrm{D} / \mathrm{H}$ ratio has on the rate of consolidation of fine-grained soils. Numerical simulation was also carried out to model test results, using PLAXIS, to show the compatibility of the numerical analysis with the test. During numerical modelling, the Mohr-Coulomb (MC) model that is probably the most used in the modelling of consolidation tests was used. This model is mostly used due to their simplicity, and specific parameters are easily obtained.

\section{EXPERIMENTAL PROCEDURE}

The sample preparation and test set up as described in the British and American standard were adopted [9, 7]. A wellknown consolidation test was carried out using the Oedometer apparatus. This test model the one-dimensional consolidation of subsoil when pressed by structures only in a vertical direction (the lateral strains are considered to be negligible). The test was run over a period of 24 hours at certain load increments under double drainage condition under equal strain (where a porous stone was used for uniform strain loading). Data were obtained using a computerised system connected to each Oedometer test with an accuracy of $\pm 0.1 \%$. The system was able to read data from six channels simultaneously.

At each $\mathrm{D} / \mathrm{H}$ ratio, the initial moisture content and void ratio were calculated from the tested fine-grained soil. The properties of the soils used (Table 1) were obtained as per the standard methods $[4,9,3,7,6]$. In order to get the undrained shear strength $\left(c_{u}\right)$, the soil was compacted at a mould $100 \mathrm{~mm}$ diameter and the vane size of $25 \mathrm{~mm}$ was used. The vane was inserted at a depth of $10 \mathrm{~mm}$ within the compacted soil with moisture content ranging from $35 \%$ to $61 \%$ with $\mathrm{c}_{\mathrm{u}}$ of 0.28 to $12 \mathrm{kN} / \mathrm{m}^{2}$ respectively. The mineralogy analysis of the soil was obtained using X-ray diffraction (XRD), and the principal clay minerals present in the clay is shown in Table1.

Table 1: Soil Properties summary

\begin{tabular}{|l|l|l|l|l|l|l|}
\hline & LL & $\mathbf{P L}$ & $\mathbf{P I}$ & $\mathbf{G}_{\mathbf{s}}$ & $\begin{array}{l}\mathbf{c}_{\mathbf{u}} \\
\left(\mathbf{k N} / \mathbf{m}^{2}\right. \\
\mathbf{2}\end{array}$ & $\begin{array}{l}\text { Mineralog } \\
\mathbf{y}\end{array}$ \\
\hline $\begin{array}{l}\text { Kaoli } \\
\text { n clay }\end{array}$ & $\begin{array}{l}63 \\
\%\end{array}$ & $\begin{array}{l}32.4 \\
\%\end{array}$ & $\begin{array}{l}30.6 \\
\%\end{array}$ & $\begin{array}{l}2 . \\
6\end{array}$ & $\begin{array}{l}0.28 \\
12\end{array}$ & $\begin{array}{l}\text { Kaolinite } \\
\text { and Quartz }\end{array}$ \\
\hline
\end{tabular}

Where; $\mathrm{LL}=$ liquid limit, $\mathrm{PL}=$ plastic limit, $\mathrm{PI}=$ plasticity index, $G_{\mathrm{s}}$ is specific gravity and $\mathrm{c}_{\mathrm{u}}=$ undrained shear strength $\left(\mathrm{kN} / \mathrm{m}^{2}\right)$

\subsection{Diameter to Height Scale Range}

A series of Oedometer tests were conducted at different $\mathrm{D} / \mathrm{H}$ ratio as shown in Table 2. For valid comparison in the $\mathrm{D} / \mathrm{H}$ ratio, the average of the initial moisture content was considered

Table-2: Scale range Oedometer tests

\begin{tabular}{|l|l|l|l|l|l|l|l|l|l|l|}
\hline D/H & 0.5 & 1 & 1.5 & $2(\mathrm{a})$ & $2(\mathrm{~b})$ & 3 & 4 & 5 & 6.5 & 11 \\
\hline Diameter $(\mathrm{mm})$ & 100 & 150 & 250 & 150 & 250 & 250 & 100 & 150 & 150 & 250 \\
\hline Height $(\mathrm{mm})$ & 200 & 130 & 200 & 80 & 130 & 80 & 23 & 30 & 23 & 23 \\
\hline Test & $\mathrm{T} 1$ & $\mathrm{~T} 2$ & $\mathrm{~T} 3$ & $\mathrm{~T} 4$ & $\mathrm{~T} 5$ & $\mathrm{~T} 6$ & $\mathrm{~T} 7$ & $\mathrm{~T} 8$ & $\mathrm{~T} 9$ & $\mathrm{~T} 10$ \\
\hline $\begin{array}{l}\text { Initial moisture } \\
\text { content }\end{array}$ & $91 \%$ & $74 \%$ & $55 \%$ & $65 \%$ & $55 \%$ & $55 \%$ & $80 \%$ & $60 \%$ & $59 \%$ & $64 \%$ \\
\hline $\begin{array}{l}\text { Average } \\
\text { moisture content }\end{array}$ & $66 \%$ & & & & & & & & & \\
\hline
\end{tabular}

\subsection{Frictionless Boundary Condition}

Previous researchers have shown that in order to reduce friction, Telfon grease is applied to the wall of the Oedometer apparatus by $\mathrm{D} / \mathrm{H}$ ratio of 6 . Kolay and Bhattacharya [17] used Telfon with kaolin soil and found that friction has an effect on $\mathrm{c}_{\mathrm{v}}$. Moreover due to this side friction in the consolidation test apparatus, the vertical pressure on any horizontal plane will decrease with sample depth. As side friction is a function of pressure, it is expected that the e-log $\mathrm{p}$ graph becomes flatter with an increase in side friction, thereby producing a small value of the compression index [16]. In the current study, Vaseline was applied to the Oedometer wall to reduce friction. Figure 1 shows the $\mathrm{e}-\log \mathrm{p}$ curve obtained in this study that contradicts the statement by Healy and Ramanjaneya [16] thus side friction was eliminated in this study. The $\mathrm{e}-\log \mathrm{p}$ curve in Figure 1 shows a gradual decrease in void ratio with an increase in pressure except at D/H 0.5 and 5 where the graph becomes flatter. Thus, taking Healy's statement, friction was not reduced at D/H 0.5 and5. 


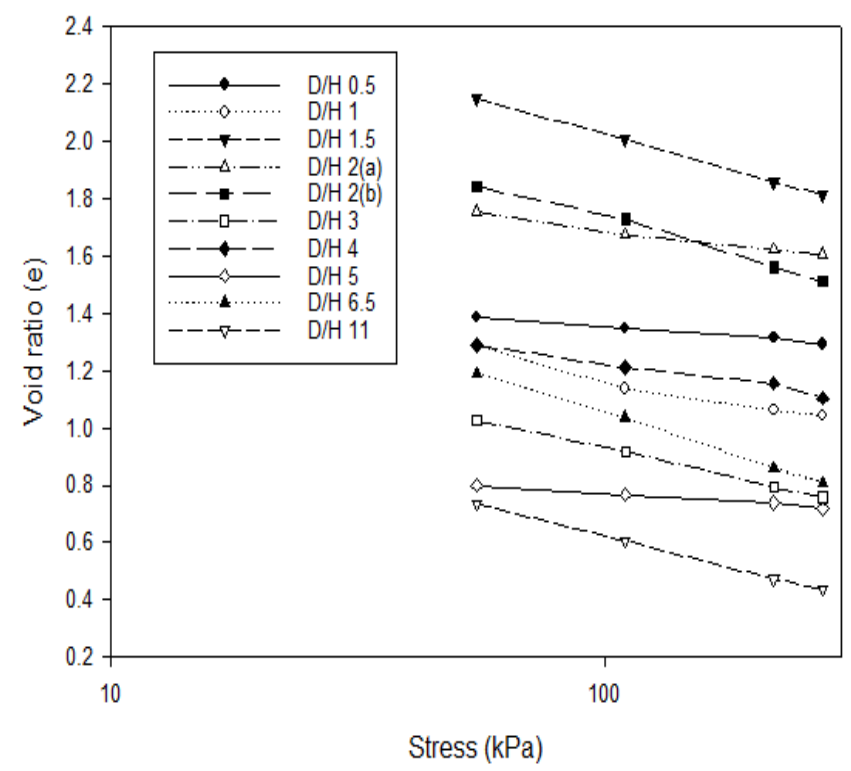

Fig-1: e-log p curve at different $\mathrm{D} / \mathrm{H}$ ratios

\subsection{Frictional Stress}

Many studies have been performed to investigate the effect of sample thickness on both primary and secondary compression. Testing soil sample in the laboratory with considerable great thickness will involve friction problem. Sivrikaya and Togrol [25] revealed that the frictional stress does not remain constant during the test and slightly increases with a decrease in time for soil thickness of $60 \mathrm{~mm}$ and diameter $75 \mathrm{~mm}(\mathrm{D} / \mathrm{H} 1.25)$. Friction was found to be most significant at low stresses where the clay soil is still over-consolidated [25]. In the current study, the clay is term normally consolidated, and Figure 1 shows friction was eliminated with reference to Healy and Ramanjaneya [16] statement. Sivrikaya and Togrol [25] derived an expression to obtain the frictional stress $(\tau)$ as shown in equation 1 .

$$
\tau=\frac{T}{\pi D H}
$$

Where, D is soil diameter ( $\mathrm{mm})$; $\mathrm{H}$ is soil height ( $\mathrm{mm})$, and $\mathrm{T}$ is the load transmitted to the ring $(\mathrm{N})$.

Figure 2 shows the application of equation 1 in the current study. It was observed that at a pressure less than $150 \mathrm{kPa}$, there is no significance difference in frictional stress. The observation was at all scales except at D/H 2(b), 6.5 and 5, where D/H 2(b) being greatly influenced. Figure 2 is contradictory to Sivrikaya and Togrol [25], where it is observed that the friction stress is most significant the high stresses for normally consolidated soils under primary consolidation. The difference in findings is due to $\mathrm{D} / \mathrm{H} 1.25$ used by Sivrikaya [25] on overconsolidated soils and 10 $\mathrm{D} / \mathrm{H}$ ratios utilised in this study on normally consolidated soils. Hence, the present study at $\mathrm{D} / \mathrm{H} 1$ and 1.5 normally consolidated can directly be compared with D/H 1.25 overconsolidated which shows the difference in findings is due to the fine-grained soil state.

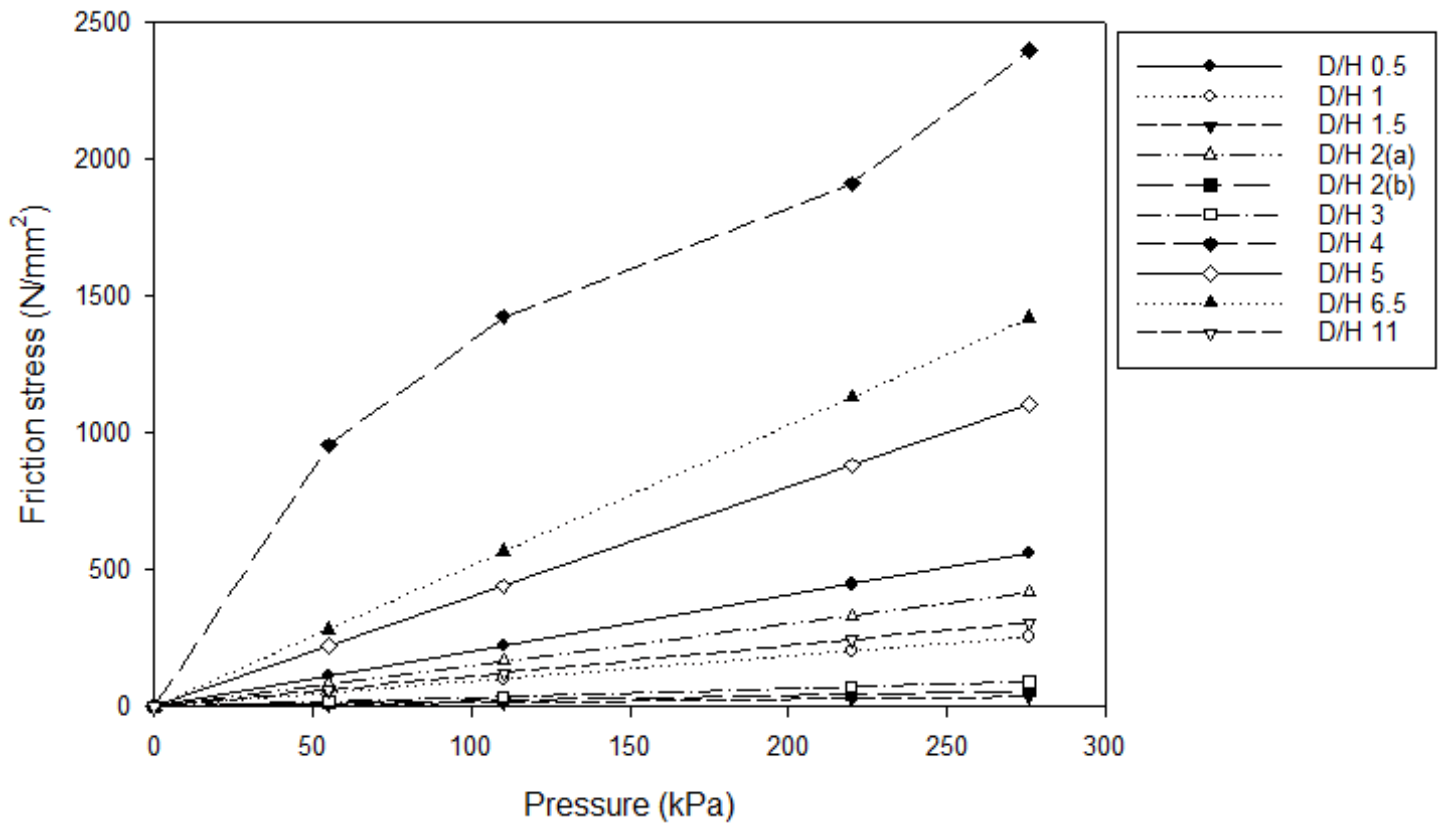

Fig-2: Frictional stresses at various $\mathrm{D} / \mathrm{H}$ ratios

\section{RESULTS}

In this section, tests arise from the laboratory model, and numerical analyses are shown. A discussion emphasised in the response of fine-grained soils at different $\mathrm{D} / \mathrm{H}$ ratio scale. Furthermore, its effect on compressibility parameters is presented.

\subsection{Experimental Results}

\subsubsection{Stress-Strain Distribution}

The vertical stress distribution within the soil matrix derived from the finite element analysis corresponding to the maximum loading and was normalized by the applied 
pressure. Figure 3 shows a variation in strain at different $\mathrm{D} / \mathrm{H}$ ratio under $55 \mathrm{kPa}$ and $110 \mathrm{kPa}$. It displays the fluctuation in strain with $\mathrm{D} / \mathrm{H}$ ratio observed at both loadings. The importance of $\mathrm{D} / \mathrm{H}$ ratio, as stated in the
American standard, is confirmed. At D/H ratio less than 2.5, the curve is difficult to construe, thus provide an uncertainty in the curve fitting procedure in obtaining the coefficient of consolidation $\left(\mathrm{c}_{\mathrm{v}}\right)$.

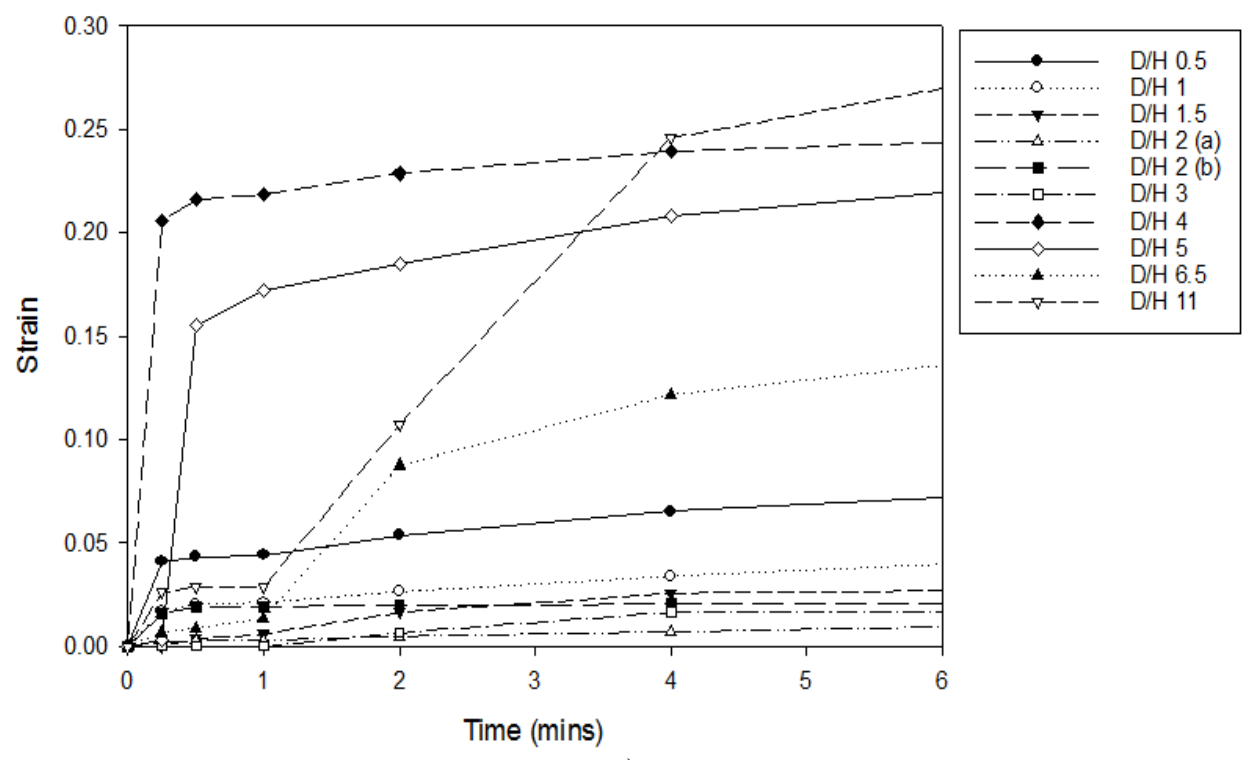

a)

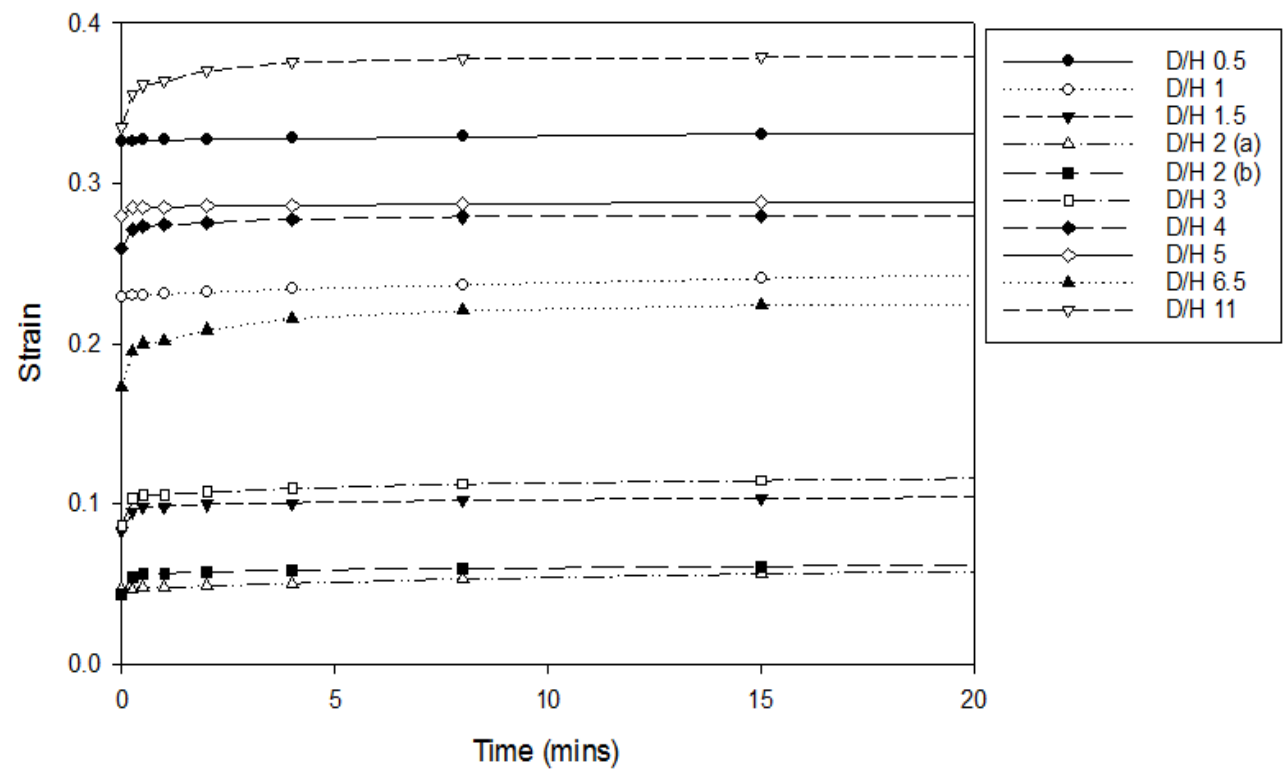

b)

Fig-3: Time-deformation relationship at: a) $55 \mathrm{kPa}$ and b) $110 \mathrm{kPa}$

\subsubsection{Effect of $\mathrm{D} / \mathrm{H}$ Ratio Scale on $\mathrm{c}_{\mathrm{c}}$ and $\mathrm{m}_{\mathrm{v}}$}

Compressibility parameters investigated were: coefficient of consolidation $\left(\mathrm{c}_{\mathrm{v}}\right)$, compression index $\left(\mathrm{c}_{\mathrm{c}}\right)$ and coefficient of volume compressibility $\left(\mathrm{m}_{\mathrm{v}}\right)$. The compressibility parameters $c_{c}$ and $m_{v}$ are important in the calculation of settlement of structures. $\mathrm{c}_{\mathrm{c}}$ is used to determine the primary consolidation settlement of the normally consolidated soil. Normally consolidated soils are a type of soil whose present effective overburden pressure is the maximum pressure that the soil was subjected to in the past [8]. Thus, the soil in this study can normally be termed consolidated. A high $\mathrm{c}_{\mathrm{c}}$ value indicates greater compressibility and higher consolidation settlements (Figure 4a). A fluctuation in $c_{c}$ value was observed with $\mathrm{D} / \mathrm{H}$ scale, as the load increases, $\mathrm{c}_{\mathrm{c}}$ reduces to a value less than 0.1 as depicted in Figure $4 \mathrm{a}$. At $55 \mathrm{kPa}$, there was a sharp rise in $c_{c}$ and $m_{v}$ with the maximum value observed at D/H 0.5 and D/H 11 respectively (Figure $4 \mathrm{~b}$ ). The lowest value is discerned at D/H $2(\mathrm{a} \& \mathrm{~b})$ for $\mathrm{c}_{\mathrm{c}}$ and $\mathrm{m}_{\mathrm{v}}$. It does show that $\mathrm{D} / \mathrm{H}$ has an influence on the magnitude of settlement and kaolin clay compressibility with correlation factor 0.052 and 0.090 for $\mathrm{c}_{\mathrm{c}}$ and $\mathrm{m}_{\mathrm{v}}$ respectively. 


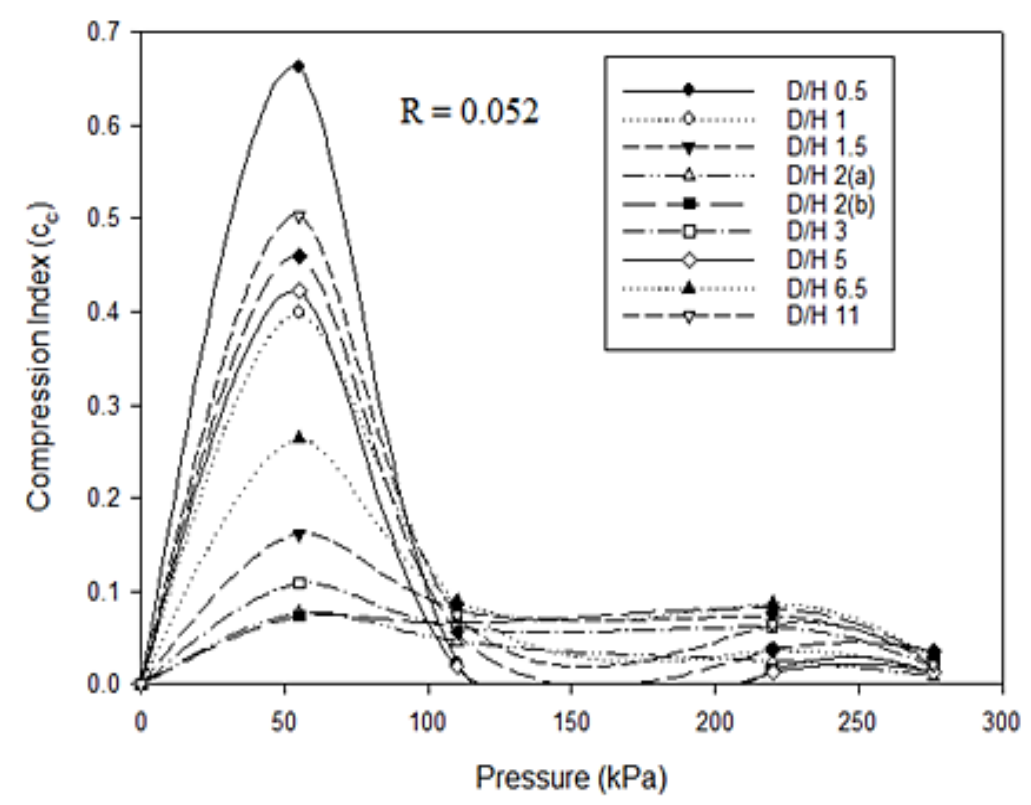

a)

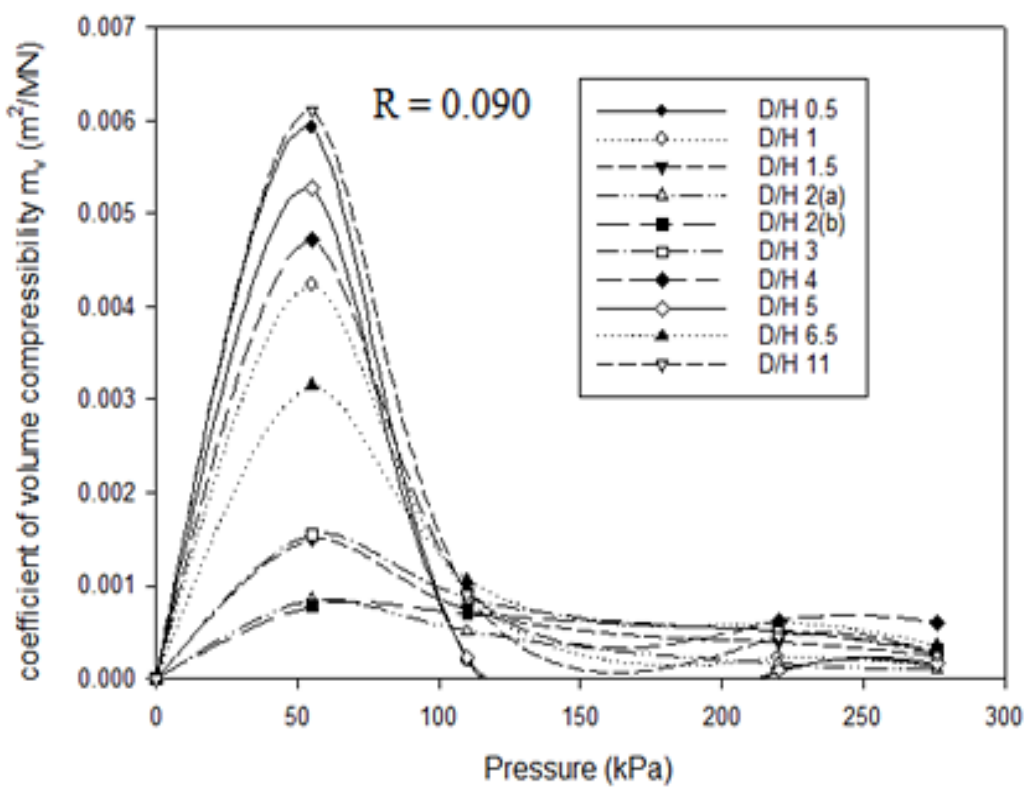

b)

Fig-4: Effect of D/H ratio on some compressibility parameters: a) $c_{c}$ and b) $m_{v}$

Data obtained shows a gradual drop in $\mathrm{m}_{\mathrm{v}}$ with pressure at all $\mathrm{D} / \mathrm{H}$ ratios except at $\mathrm{D} / \mathrm{H} 0.5$ and $5 . \mathrm{m}_{\mathrm{v}}$ was found to reduce at $220 \mathrm{kPa}$ and increase at $276 \mathrm{kPa}$ by $72 \%$ and $60 \%$ respectively (Figure $4 \mathrm{~b}$ ). The findings validate that by Retnamony et al. [22], where $\mathrm{m}_{\mathrm{v}}$ was found to decrease with an increase in pressure for kaolinite soil except at $\mathrm{D} / \mathrm{H} 0.5$ and 5 at $220-276 \mathrm{kPa}$. Thus, D/H scale has an effect on soil compressibility; nevertheless, the outcome is less significant with the overall $\mathrm{m}_{\mathrm{v}}$ value being less than $0.006 \mathrm{~m}^{2} / \mathrm{MN}$ exhibiting a very low compressibility.
3.1.3 Effect of D/H Ratio on the Ratio of $\left[c_{v}(\sqrt{t}) / c_{v}\right.$

\section{$(\log t)]$}

The values of $\mathrm{c}_{\mathrm{v}}$ were determined using Casagrande, Taylor, and Inflection methods. Statistical analysis was carried out using SPSS for a total of $120 \mathrm{c}_{\mathrm{v}}$ values at various D/H ratios. The analysis demonstrates the statistical significance of the value of $c_{v}$ obtained using different methods. The outcome showed a normality in $\mathrm{c}_{\mathrm{v}}$ values at all scale except at D/H 5 . At $\mathrm{D} / \mathrm{H} 5$, the values of $\mathrm{c}_{\mathrm{v}}$ were abnormal due to an outlier found, which is due to the experimental curve not matching the theoretical curve. There is no substantial difference in $c_{v}$ value attained using the different method with a sizeable 
difference of 0.003 . Thus, the value of $c_{v}$ obtained using either test method is not significantly different. Hence, Taylor's method was found to be precisely more adequate to get $c_{v}$ where scale is a concern (Figure 5b) [26]. As compared to Casagrande and Inflection method, $\mathrm{c}_{\mathrm{v}}$ was affected by the curve fitting procedure [11, 13, 20]. The relationship in $c_{v}$ with pressure obtained using the three method are depicted in Figure 5. The $\sqrt{\mathrm{t}}$ curve fitting process was a straightforward process as the primary consolidation part of the curve was easily identified. The issue with the remaining methods at $\mathrm{D} / \mathrm{H}$ less than 2.5 especially at $\mathrm{D} / \mathrm{H} 0.5$ was that the secondary consolidation was not clearly observed rendering difficulty in deriving $c_{v}$ from curve fitting procedure.

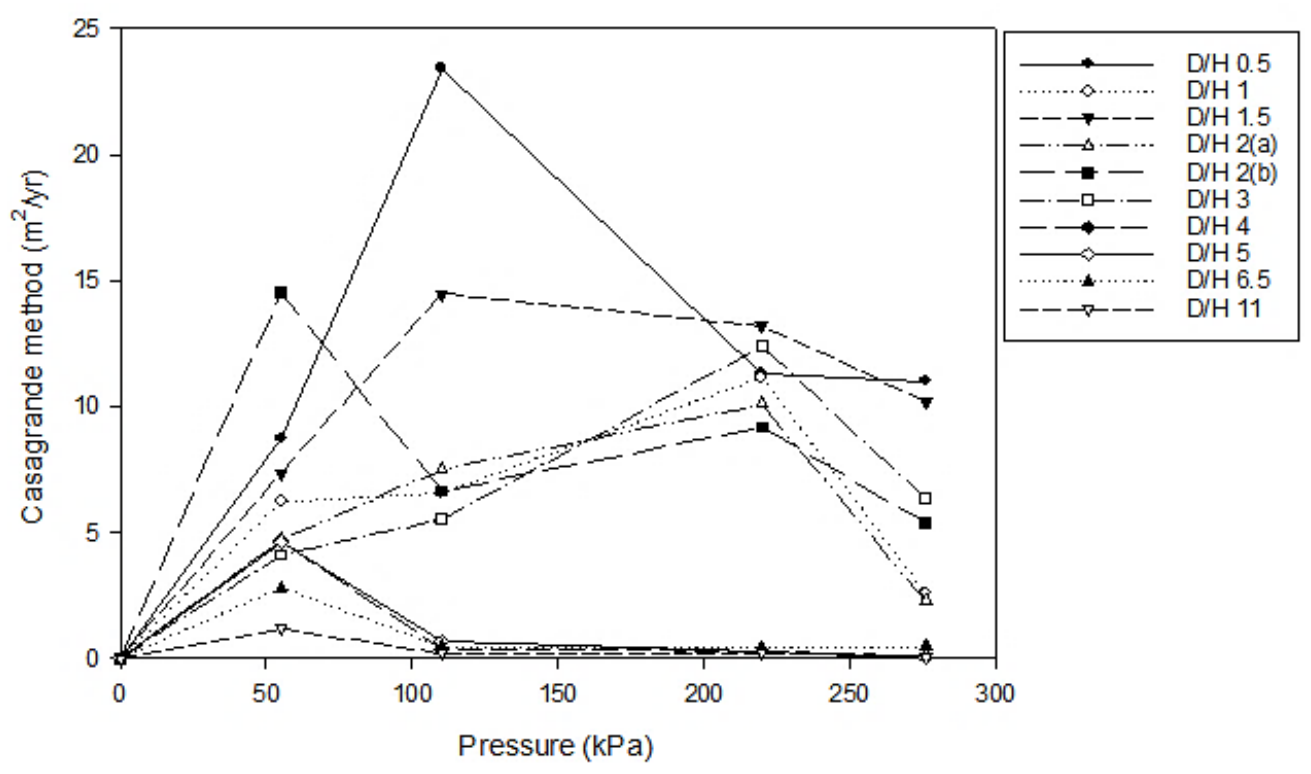

a)

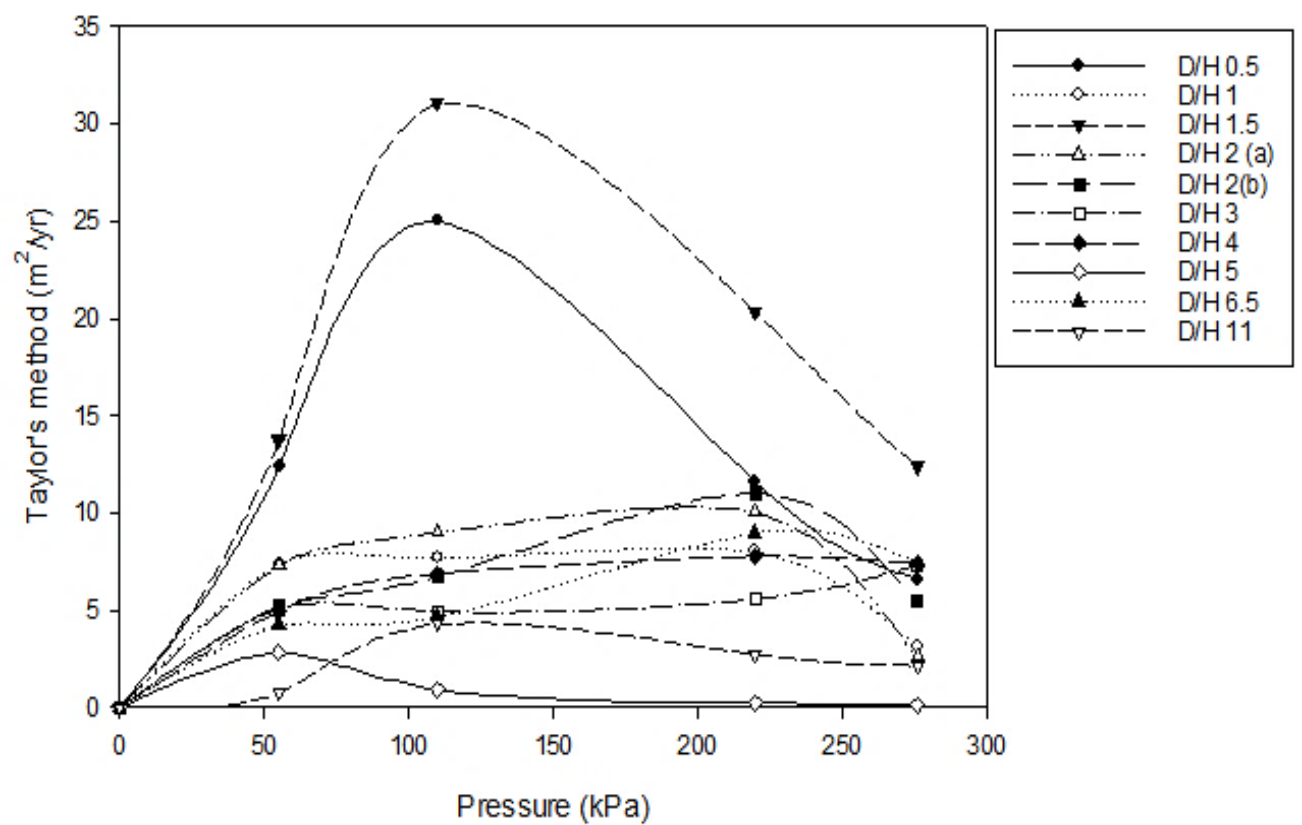

b) 


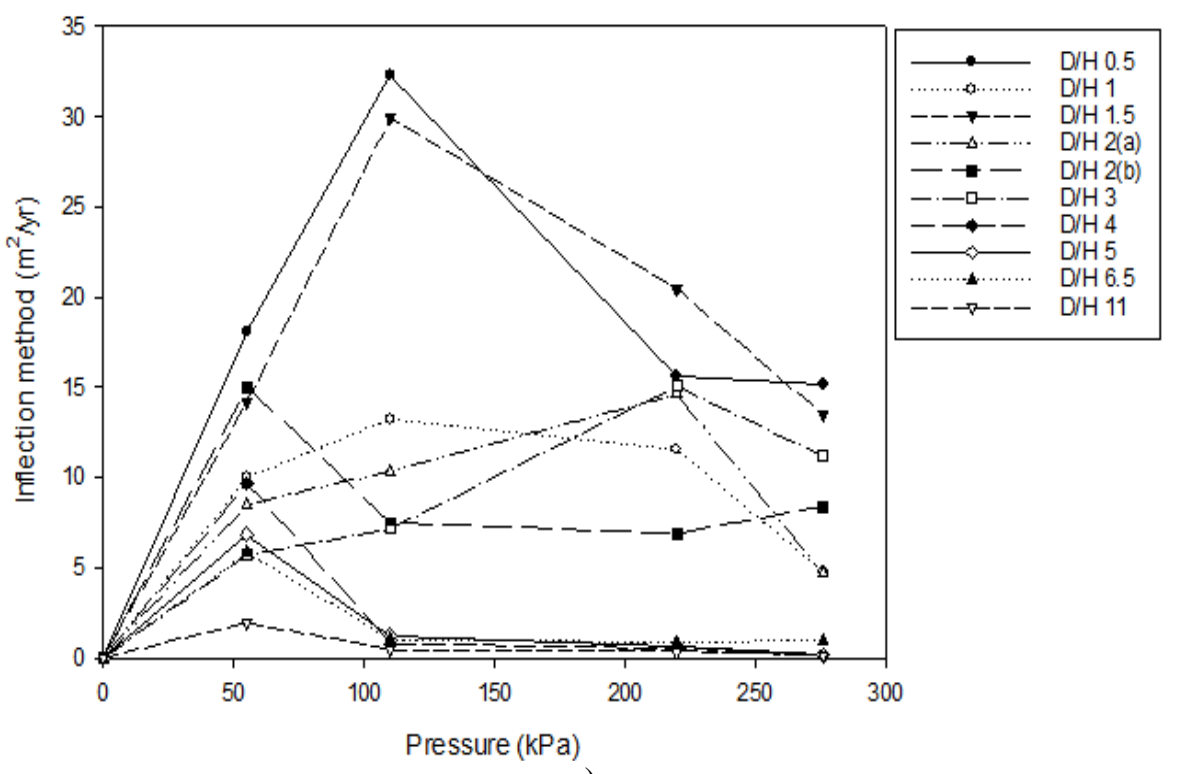

c)

Fig-5: Applied pressure against the coefficient of consolidation $\left(\mathrm{c}_{\mathrm{v}}\right)$ obtained at a) Casagrande method, b) Taylor's method and c) Inflection method

Previous researcher's showed that $\mathrm{c}_{\mathrm{v}}$ obtained using Taylor's method is higher than that attained using Casagrande method and Inflection method gives quite a similar result to that of Casagrande method [2, 12, 20, 23]. The reason being; Taylor's method is affected by the initial compression (leading to an increase in $\mathrm{c}_{\mathrm{v}}$ ) and in some cases secondary compression (decrease in $c_{v}$ value). Casagrande and Inflection method are mostly dependent on a certain amount of secondary compression being observed on the strain-deformation curve. In the current study, the opposite was found where the highest value in $\mathrm{c}_{\mathrm{v}}$ was attained using the Inflection method, and Taylor's method produced the lowest value. The cause of this is due to $\mathrm{D} / \mathrm{H}$ scale at a particular scale $(\mathrm{D} / \mathrm{H}<2.5)$. Figure 6 shows the ratio of $\mathrm{c}_{\mathrm{v}}$ $\sqrt{t} / \log t_{50}, c_{v} \sqrt{t} / \log t_{60}$ and $c_{v} \log t_{50} / c_{v} \log t_{60}$ with D/H ratio scale. The outliers in Figure 6 are observed at D/H less than 2.5 and are due to the experimental curve not matching the theoretical curve. The outliers present the uncertainty in the curve fitting process at $\mathrm{D} / \mathrm{H}<2.5$ and the validity of the recommended value by the standard. Therefore, $\mathrm{D} / \mathrm{H}>2.5$ is adopted as per the standard and values showed to be closely packed together. Despite the outliers, the inflection and Casagrande method was found to correlate well as deduced by previous researchers.

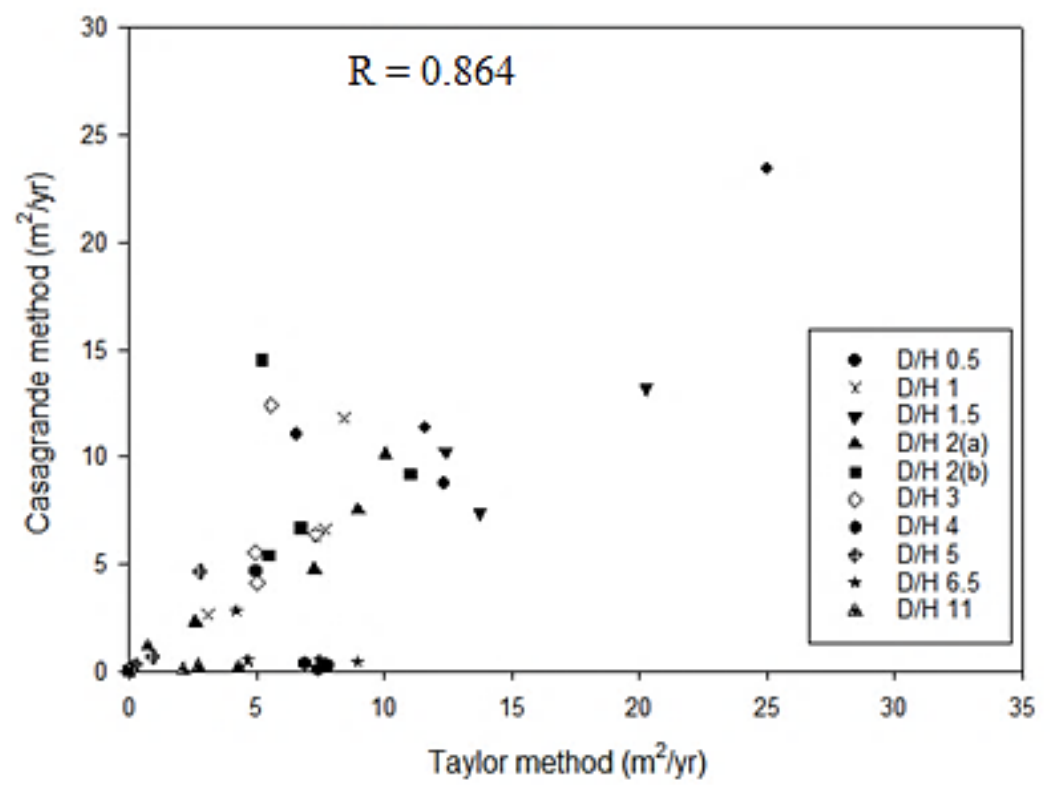

a) 


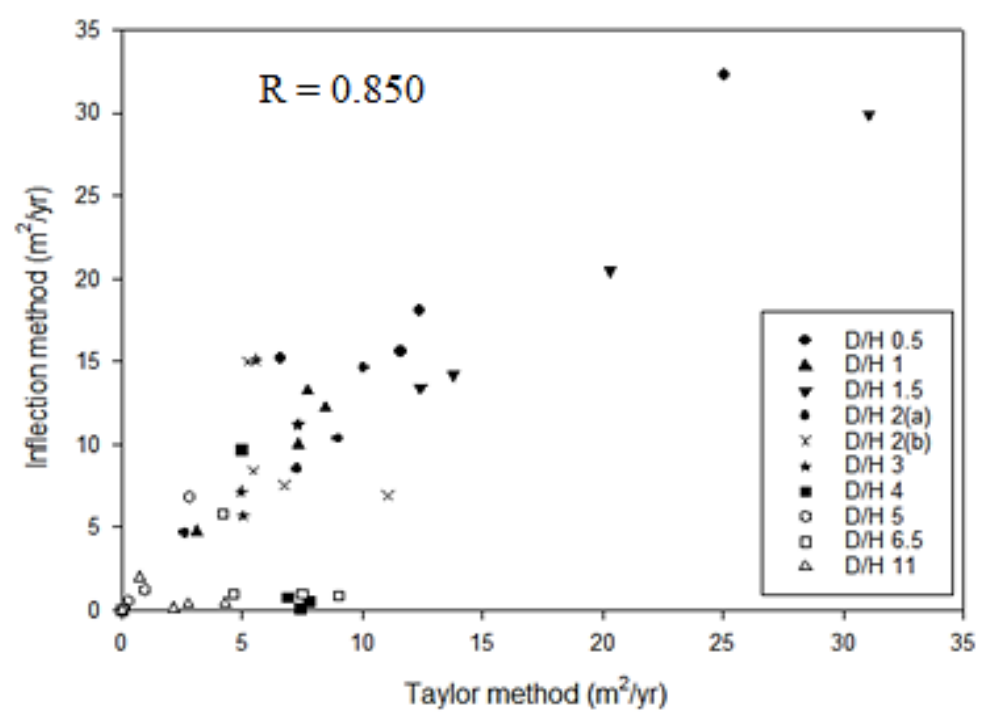

b)

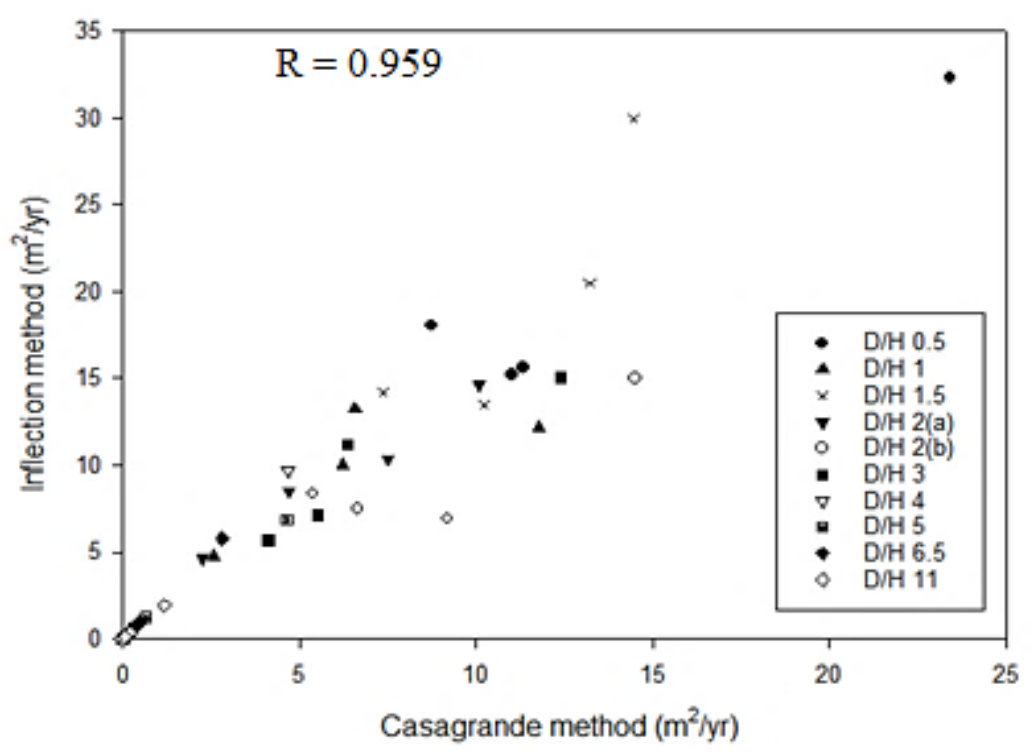

c)

Fig-6: $c_{v} \sqrt{t} / \log t$ ratio at various $\mathrm{D} / \mathrm{H}$ ratio

\subsection{Numerical Simulation}

Finite element analyses were implemented to validate experimental results on the validity of $\mathrm{D} / \mathrm{H}$ ratio scale on fine-grained soils. The $\mathrm{D} / \mathrm{H}$ ratio model was completed using the Mohr-Coulomb model (MC). The finite element model (FEM) was firstly calibrated against the experimental data.

\subsubsection{Finite Element Model}

A geotechnical finite element program PLAXIS was used for the simulation of the fully saturated fine-grained soils at diverse $\mathrm{D} / \mathrm{H}$ ratios. The one-dimensional model was axisymmetric and discretized using 16 nodes elements. The young's modulus was assumed to be $1000 \mathrm{kN} / \mathrm{m}^{2}$, and a default coefficient of permeability $(k)$ was employed in
PLAXIS with value $5.5 \times 10^{-7} \mathrm{~m} / \mathrm{s}$. The boundary conditions were set as permeable at both the top and bottom of the soil profile with the side being impermeable. In order to achieve comparative curve to the experimental data, the vertical load was applied in double increments.

\subsubsection{Model Calibration}

In order to establish the validity of the FEM, it was first compared with the experimental data under hydraulic loading at different $\mathrm{D} / \mathrm{H}$ ratio scale with an average initial moisture content of $66 \%$. Figure 7 shows the comparison between the experimental data and FEM, which shows that the FEM can simulate the stress-strain deformation of finegrained soil with good accuracy with a maximum difference of $2 \%$. The properties of the studied fine-grained soil used to calibrate the model as is as shown in Table 3. 
Table-3: Fine-grained soil used in calibration of model

\begin{tabular}{|l|l|l|l|l|l|l|l|l|l|l|}
\hline Scale & D/H 0.5 & D/H 1 & D/H 1.5 & D/H 2(a) & D/H 2(b) & D/H 3 & D/H 4 & D/H 5 & D/H 6.5 & D/H 11 \\
\hline $\mathrm{e}$ & 2.53 & 2.49 & 2.43 & 1.88 & 1.97 & 1.20 & 2.09 & 1.50 & 1.65 & 1.61 \\
\hline $\mathrm{c}_{\mathrm{u}}$ & 12.00 & 12.00 & 12.00 & 12.00 & 12.00 & 12.00 & 12.00 & 12.00 & 12.00 & 12.00 \\
\hline$\gamma_{\text {sat }}$ & 14.33 & 15.00 & 14.40 & 15.20 & 15.40 & 17.00 & 17.30 & 15.90 & 15.70 & 15.8 \\
\hline
\end{tabular}

Where; e is the void ratio, $\mathrm{c}_{\mathrm{u}}$ is the undrained shear strength $\left(\mathrm{kN} / \mathrm{m}^{2}\right)$, and $\gamma_{\mathrm{sat}}$ is the saturated unit weight $\left(\mathrm{kN} / \mathrm{m}^{3}\right)$.
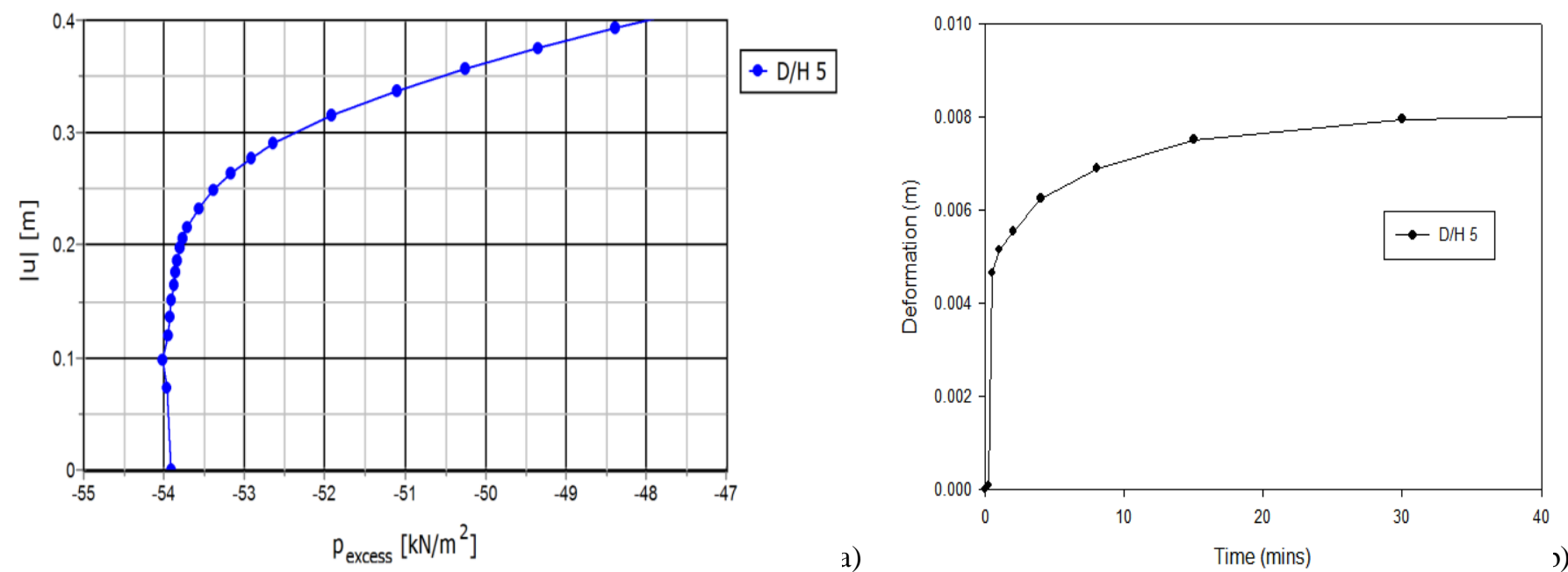

Fig-7: Comparison between experimental and numerical model at 110kPa for D/H 1; a) normalised FEM and b) experimental model. Where; $p_{\text {excess }}$ is the excess pore pressure and $|\mathrm{u}|$ is the soil deformation

\subsubsection{Excess Pore Pressure Distribution}

Practically, during consolidation under double drainage, an excess pore water pressure $\left(\mathrm{P}_{\text {excess }}\right)$ is observed at the midheight of the soil matrix. Figure 8 shows the difference in excess pore pressure at various $\mathrm{D} / \mathrm{H}$ ratios ranging from 0.5 to 11 . It clearly shows that, as the $\mathrm{D} / \mathrm{H}$ increases, $\mathrm{P}_{\text {excess }}$ concentration in the mid-height of the soil matrix increases. At $\mathrm{D} / \mathrm{H} 0.5, \mathrm{P}_{\text {excess }}$ is observed at the top of the soil, which is mainly due to the scale and applied pressure proportion to the soil profile. The proportion relates to the ratio of applied
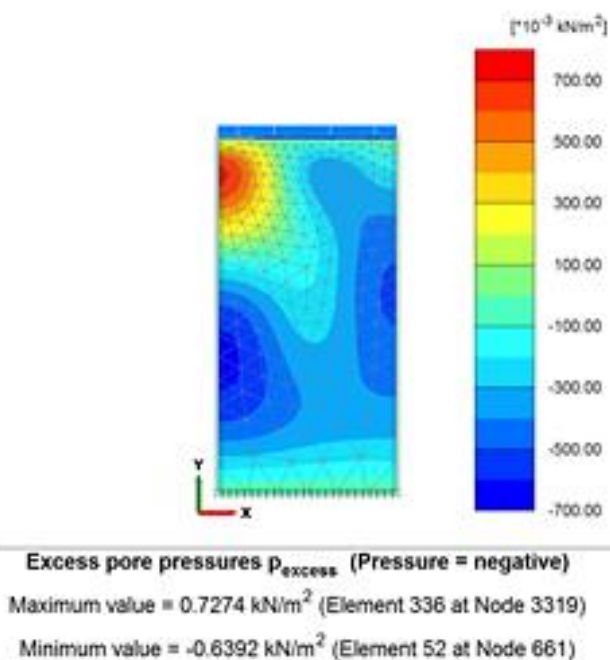

Minimum value $=-0.6392 \mathrm{kN} / \mathrm{m}^{2}$ (Element 52 at Node 681) pressure to scale on a fully saturated soil. Due to the pressure being $55 \mathrm{kPa}$ at $\mathrm{D} / \mathrm{H} 0.5$ under 24 hours, the ratio of the pressure on the soil profile is trivial. However, as the pressure increase, $\mathrm{P}_{\text {excess }}$ was observed at the bottom of the soil. Therefore, at $\mathrm{D} / \mathrm{H}$ less than 2 fluctuations in behaviour are found as compared to $\mathrm{D} / \mathrm{H}$ greater than 2 . Thus, the minor difference in the recommended standard method is not significant as the findings still validate that stated in the British and American standard.

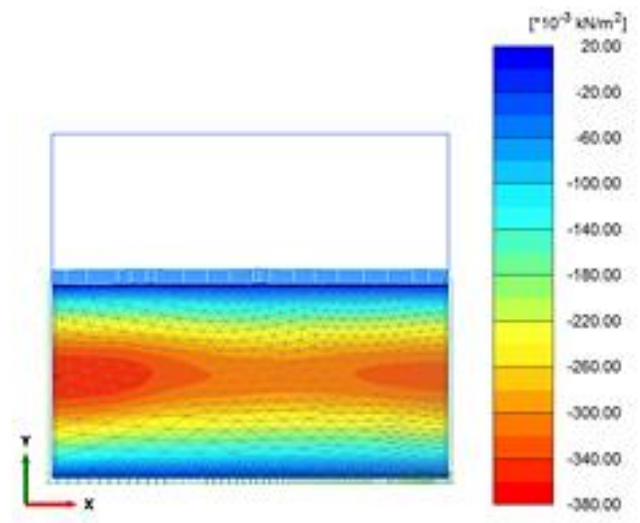

\footnotetext{
Excess pore pressures $p_{\text {ences }}$ (Pressure $=$ negative) Maximum value $=0.05171 \cdot 10^{-3} \mathrm{kN}^{2} \mathrm{~m}^{2}$ (Element 949 at Node 5217) Minimum value $=-0.3603 \mathrm{kN}^{2} \mathrm{~m}^{2}$ (Element 26 at Node 7279$)$
} 


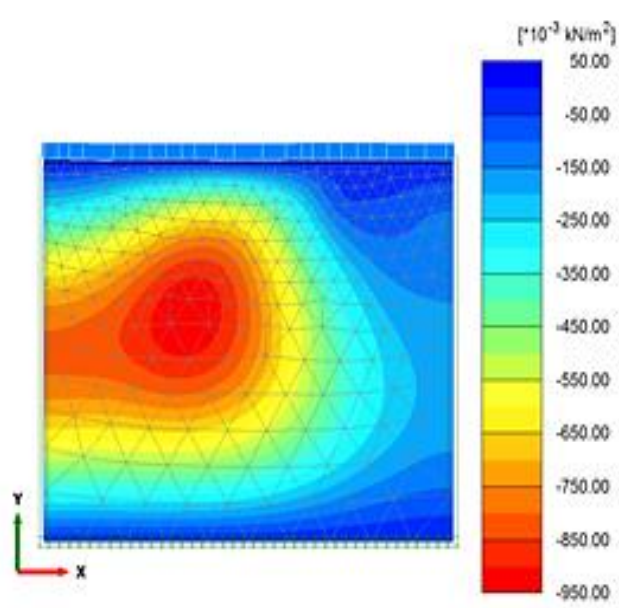

Excess pore pressures $\mathrm{p}_{\text {excess }}$ (Pressure $=$ negative) Maximum value $=0.3481 * 10^{-3} \mathrm{kN} / \mathrm{m}^{2}$ (Element 439 at Node 4248)

Minimum value $=.0 .9410 \mathrm{kN} / \mathrm{m}^{2}$ (Element 142 at Node 2808)

c)

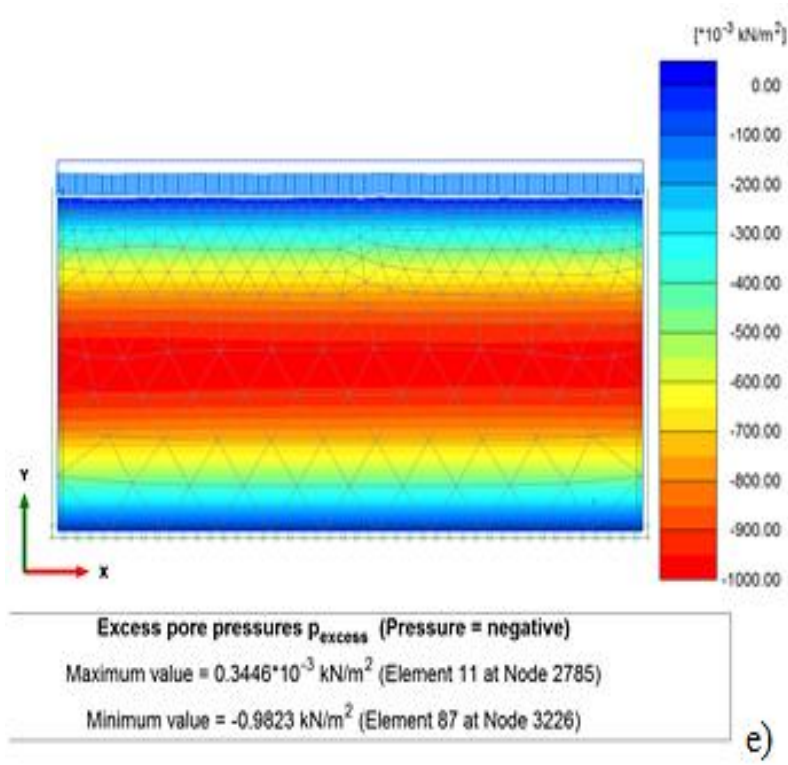

e)

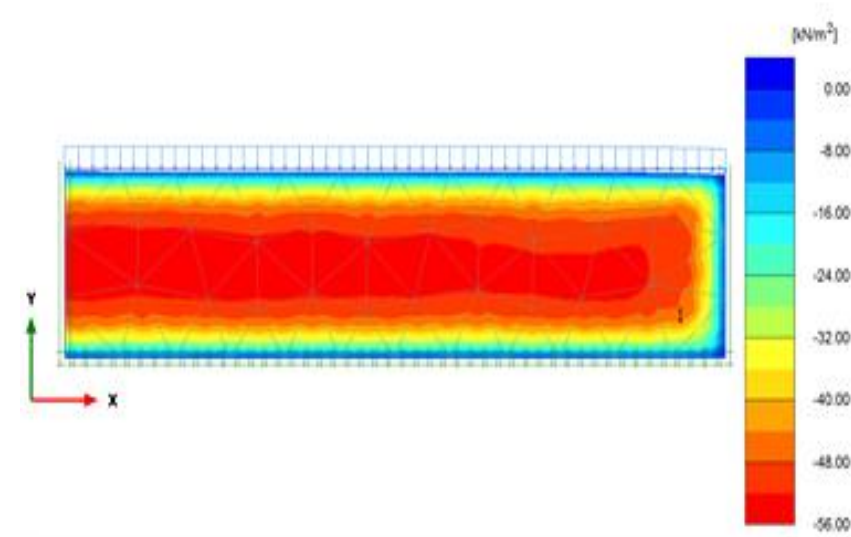

Excess pore pressures $\mathrm{p}_{\text {exeess }}$ (Pressure $=$ negative)

Maximum value $=0.2682 \mathrm{kN} / \mathrm{m}^{2}$ (Element 62 at Node 4$)$

Minimum value $=-53.81 \mathrm{kN/m^{2 }}$ (Element 68 at Node 589$)$
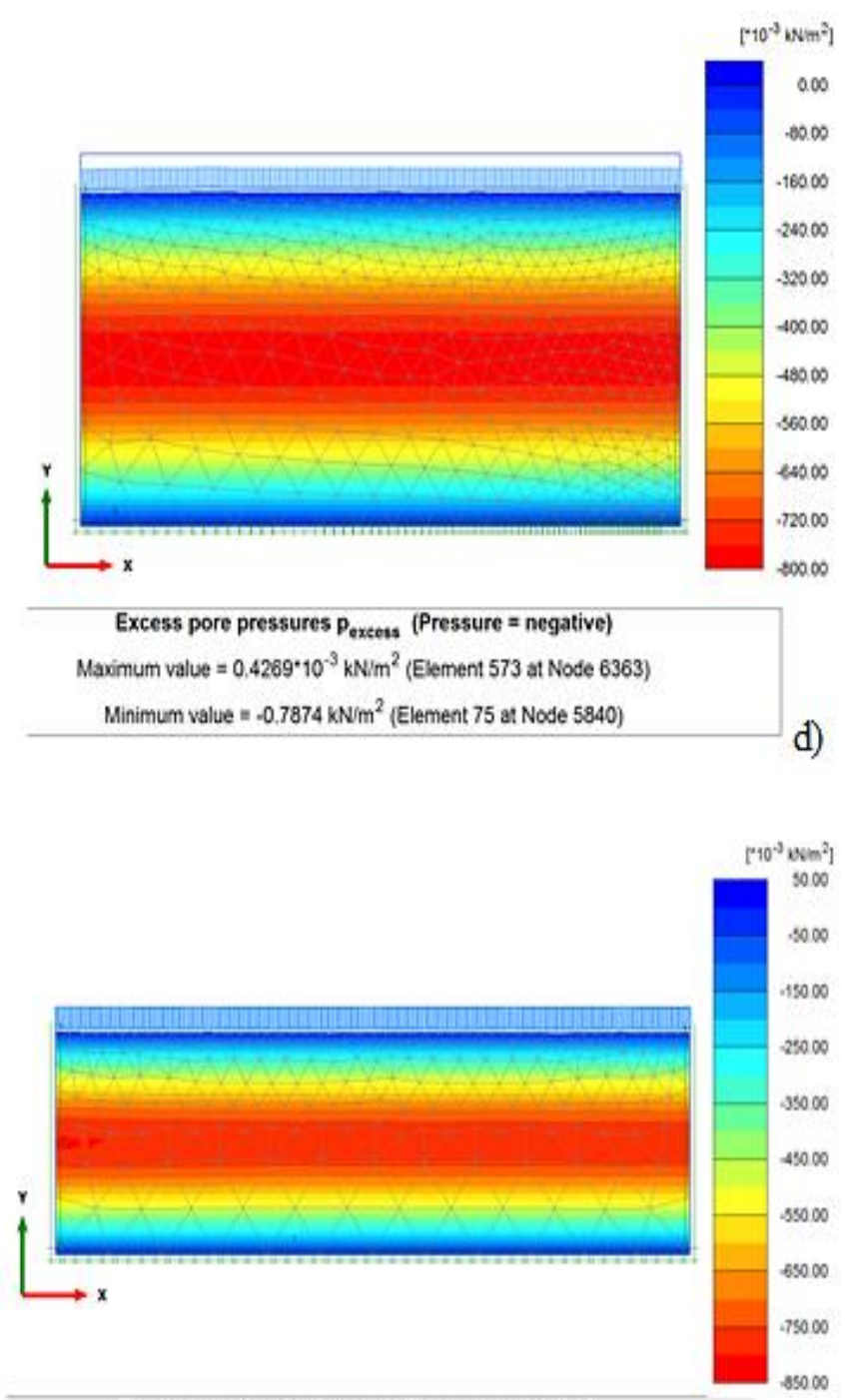

Excess pore pressures $\mathrm{p}_{\text {excess }}$ (Pressure $=$ negative)

Maximum value $=0.3081 \cdot 10^{-3} \mathrm{kN} / \mathrm{m}^{2}$ (Element 365 at Node 2)

Minimum value $=0.00032 \mathrm{kNm}^{2}$ (Element 55 at Node 476)

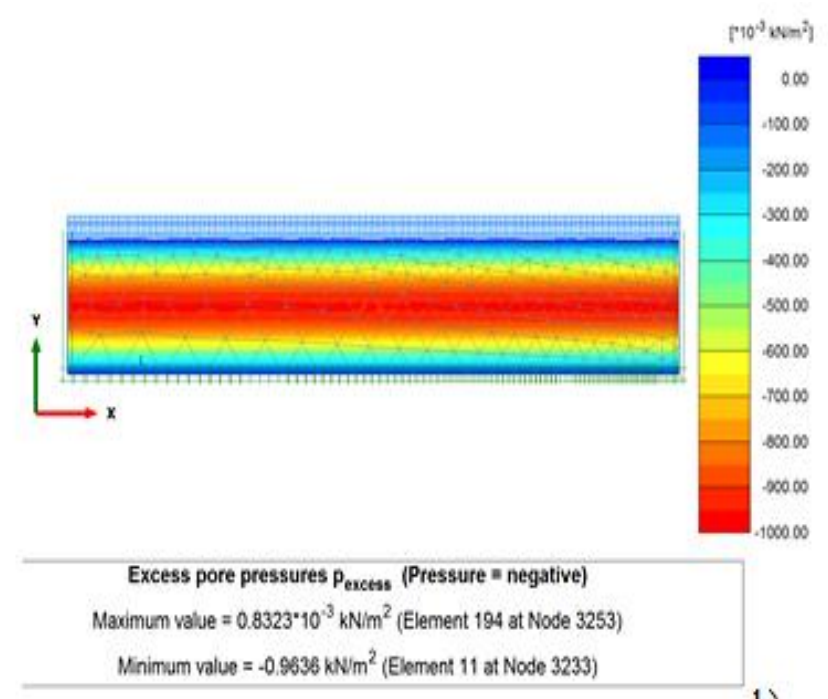

g) 


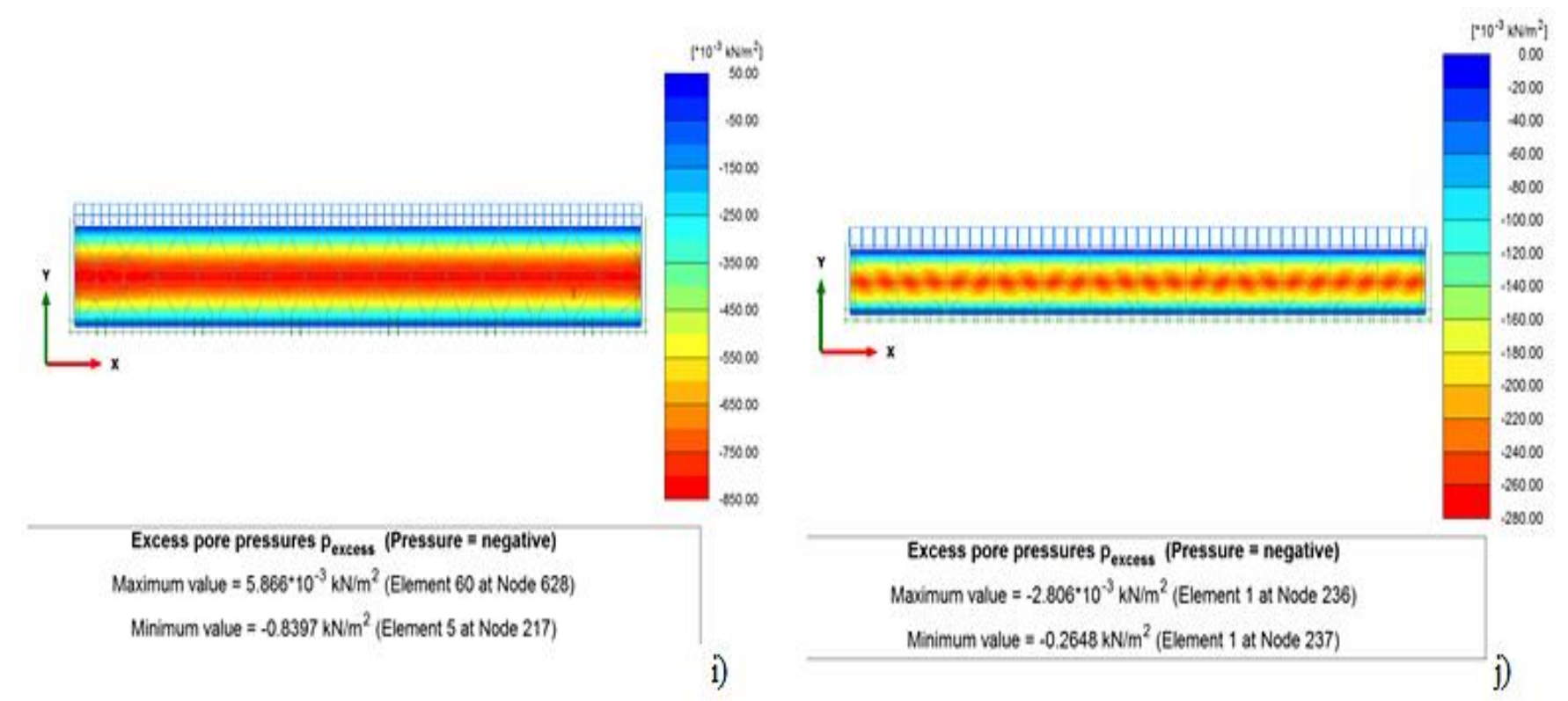

Fig-8: Excess pore water pressure distribution under double drainage at different $\mathrm{D} / \mathrm{H}$ ratio scale at $55 \mathrm{kPa}$ : a) $\mathrm{D} / \mathrm{H} 0.5$, b) $\mathrm{D} / \mathrm{H} 1$, c) D/H 1.5, d) D/H 2(a), e) D/H 2(b), f) D/H 3, g) D/H 4, h) D/H 5, i) D/H 6.5 and j) D/H 11

In addition, from the trends discerned in Figure $8, \mathrm{D} / \mathrm{H}$ yielded the highest excess pore pressure with the lowest being observed at D/H 11. However, the value of $\mathrm{D} / \mathrm{H} 0.5$ can be deemed less accurate as the trend does not correspond to the remaining scales. The flaws in trend at D/H 0.5 was observed experimentally where the highest $c_{v}$ and $c_{c}$ values were noted at this magnitude. Nevertheless, $\mathrm{D} / \mathrm{H} 1$ and $2(\mathrm{a} \& \mathrm{~b})$ showed to produce adequate results that are relatively comparable to the remaining scale. The maximum values of $\mathrm{P}_{\text {excess }}$ at $\mathrm{D} / \mathrm{H} 1.5$ and $\mathrm{D} / \mathrm{H} 2(\mathrm{a} \& \mathrm{~b})$ are more or less analogous by $81 \%$ and $98 \%$ respectively.

\section{CONCLUSION}

A study of the influence of $\mathrm{D} / \mathrm{H}$ ratio on compressibility parameters was investigated. The significant influence of $\mathrm{D} / \mathrm{H}$ ratio was noticed on $\mathrm{c}_{\mathrm{v}}$ but was insignificant in $\mathrm{c}_{\mathrm{c}}$ and $\mathrm{m}_{\mathrm{v}}$. It was previously studied that scale has an impact on $\mathrm{c}_{\mathrm{v}}$ but not taking $\mathrm{D} / \mathrm{H}$ ratio into account. $\mathrm{D} / \mathrm{H}$ ratio was previously investigated at D/H 3 and 6 and showed it greatly affect $c_{v}$ and $\mathrm{D} / \mathrm{H}$ greater than 6 recommended. The Standards suggested 2.5 and 4 . The current study on Kaolin clay showed that, at $\mathrm{D} / \mathrm{H}$ greater than 1 , adequate result in the compressibility parameters are obtained. Previous recommended $\mathrm{D} / \mathrm{H}$ ratio values were in different soil sample thus the difference $\mathrm{D} / \mathrm{H}$ ratio values. $\mathrm{D} / \mathrm{H} 0.5$ showed to be most problematic in obtaining the compressibility parameters, and this was observed numerical where the highest excess pore pressure was noted. In addition, Casagrande and Inflection method were strenuous as the experimental curve did not match the theoretical curve. Therefore, in the absence of friction that is not usually obtained in routine testing, it was observed that in terms of $\mathrm{D} / \mathrm{H}$ ratio, $\mathrm{c}_{\mathrm{v}}$ is easily attained using Taylor's method.

\section{REFERENCES}

[1]. N. Abbasi, A.A. Javadi and R. Bahramloo. 'Prediction of Compression Behaviour of Normally Consolidated finegrained soils' World Applied Science Journal, 2012, 18(1), Pp.6-14

[2]. M.S. Al-Zoubi. 'Consolidation analysis by the Slope and Settlement Rate - Settlement Methods. Journal of Civil Engineering, 7(4), 2013, pp. 377-391

[3]. American Society For Testing And Materials, 'D854'. 'Standard test methods for specific gravity of soil solids by water pycnometer', 2010

[4]. American Society For Testing And Materials, 'D2216'. 'Standard test methods for laboratory determination of water (moisture) content of soil and rock by mass', 2010

[5]. American Society For Testing And Material, 'D2435'. 'Standard test method for one-dimensional consolidation properties of soils', 2003

[6]. American Standard For Testing and Material, 'D2571'. 'Standard test method for field vane shear test in cohesive soils', 2001.

[7]. American Society For Testing And Materials, 'D4318'. 'Standard test method for liquid limit, Plastic limit and plasticity index of soils', 2010.

[8]. P.L. Berry and D. Reid. 'An introduction to soil mechanics', McGraw-Hill, 1987, Pp.100-137

[9] British Standard, BS1377: PART 2. 'Methods of tests for soils for civil engineering purposes - Classification Tests', 1990.

[10]. British Standard, BS1377: Part 5. 'Methods of tests for soils for civil engineering purposes - Compressibility, permeability and durability tests', 1990.

[11]. A. Casagrande and R.E. Fadum. 'Notes on soil testing for engineering purposes' Soil Mechanics Series. Graduate school of engineering, Harward University, Cambridge, M.A, 1940 
[12]. G. Cortellazzo. 'Comparison between laboratory and in situ values of the coefficient of primary consolidation $\mathrm{c}_{\mathrm{v}}$ ' Canadian Geotechnical Journal, 2002, 39, Pp.103-110

[13]. F.F Cour. 'Inflection point method for computing $\mathrm{c}_{\mathrm{v}}$ '. Journal of the soil mechanics and foundation Engineering Division, 1971, ASCE, 97 (5), Pp. 827-831

[14]. N. Dirgeliene, A. Jonas A and V. Stragys. 'Effects of end conditions on soil shear strength parameters during Triaxial Testing' 2007, Pp. 1-6, http://leidykla.vgtu.lt/conferences/MBM_2007/5pdf/Dirgelie ne.pdf

[15]. R.D. Grisso, C.E Johnson, A.C Bailey and T.A Nichols. 'Influences of soil sample geometry on hydrostatic compaction' American Society of Agricultural Engineers, DOI: 0001-2351/84/2706-1650\$02.00, 1984, Pp.1650-1653

[16]. K.A Healy and G.S Ramanjaneya. 'Consolidation characteristic of a Varved Clay' Report, Department of Civil Engineering, University of Connecticut, 1970.

[17]. Kolay P. \& Bhattacharya G. Remediation of the side friction in conventional oedometer tests by using large diameter consolidometer ring. International Journal of Geotechnical Engineering, 2(2), 2008, Pp.161-167

[18]. N.R Kotiya and M.G Vanza. 'Effect of H/D ratio on stress-strain characteristics of clayey soil in Triaxial Test' Indian Journal of Research, 2013, 2(7), ISSN - 2250-1991, 2, Pp.101-103

[19]. G.A Leonards and P. Girault. 'A study of the onedimensional consolidation test' Proceedings fifth international conference on soil mechanics and foundation engineering, Vol.1, 1961

[20]. G. Mesri, T.W Feng and M. Shabien. 'Coefficient of Consolidation by Inflection point method' Journal of geotechnical and geoenvironmental engineering, 1999, Pp. 716-1212

[21]. P. Morris and D. Lockington. 'Geotechnical Compressibility and consolidation parameters and correlations for remoulded fine-grained marine and riverine sediments' Research Report, CRC for Sustainable Tourism, 2002, P.26

[22]. G. Retnamony, R.G. Robinson and M.A Mether. 'Effect of clay mineralogy on the coefficient of consolidation' Clay and Minerals, 1998, 46 (5), Pp. 596-600 [23]. R.G. Robinson. 'Consolidation analysis with pore water pressure measurements' Geotechnique, 1999, 49(1), Pp. 127-132

[24]. A. Singh and S. Noor. 'Soil Compression Index Prediction Model for Fine-grained soils' International Journal of Innovations in Engineering and Technology (IJLTET), 2012, 1(4), Pp.34-37

[25]. O. Sivrikaya and E. Togrol. 'Measurement of side Friction between specimen and consolidation Ring with Newly Designed Oedometer Cell' Geotechnical Testing Journal, 2006, 29 (1)

[26]. D.W Taylor. 'Research on consolidation of clays. Massachusetts Institute of Technology' Cambridge, 1942 